\title{
PENGARUH PEMBELAJARAN BERBASIS MULTIMEDIA DAN PETA KONSEP TERHADAP KOMPETENSI MAHASISWA DALAM PROTEKSISISTEM TENAGA LISTRIK
}

\author{
Sriadhi \\ sriadhi01@yahoo.co.id
}

\begin{abstract}
ABSTRAK
Studi ini mengungkap pengaruh model pembelajaran terhadap kompetensi mahasiswa dalam mata kuliah Proteksi Sistem Tenaga Listrik. Kelompok eksperimen pembelajaran berbasis multimedia dengan sampel 38 orang dan pembelajaran strategi peta konsep 36 orang. Analisis data menggunakan statistik komparasi dua mean pada taraf $\alpha=5 \%$. Hasil penelitian menemukan bahwa pembelajaran berbasis multimedia meningkatkan capaian kompetensi (A) sebesar 34,2\% ; kegagalan 0\% dan indeks nilai 3,48. Pembelajaran strategi peta konsep meningkatkan capaian kompetensi (A) sebesar 27,8\%; kegagalan 5,6\% dan indeks nilai 3,11. Kedua model pembelajaran berbeda secara signifikan dalam capaian hasil belajar dan pembelajaran berbasis multimedia terbukti lebih efektif dibandingkan strategi peta konsep pada taraf signifikansi $\alpha=5 \%$. Untuk selanjutnya perlu dilakukan penelitian dengan menyertakan gaya belajar mahasiswa sebagai variabel moderator sehingga akan diketahui interaksinya dengan model pembelajaran dalam upaya meningkatkan kapabilitas hasil belajar mahasiswa.
\end{abstract}

Kata kunci : multimedia, peta konsep, kompetensi, proteksi tenaga listrik.

\section{Pendahuluan}

Program studi Pendidikan Teknik Elektro FT Unimed menghadapi masalah berkenaan dengan rendahnya hasil belajar mahasiswa, terutama dalam mata kuliah Proteksi Sistem Tenaga Listrik (Sriadhi, 2013). Hasil tes kompetensi bidang sistem proteksi tiga tahun terakhir rata-rata hanya $13,12 \%$ mencapai jenjang kompeten (A); $62,50 \%$ cukup kompeten (B); 15,57\% kurang kompeten (C); dan $8,81 \%$ tidak kompeten (D \& E).Kondisi ini masih jauh dari target yang ditetapkan yaitu capaian kelulusan dengan tingkat kompeten $(\mathrm{A}) \geq$ 40\%(Sriadhi, 2013).

Tidak tercapainya target kompetensi dimaksud karena beberapa kelemahan mahasiswa, antara lain (1) Kurangnya penguasaan tentang konsep-konsep dasar dan prinsip kerja peralatan proteksi; (2) Kurangnya pemahaman mahasiswa tentang sistem ketenaga-listrikan; (3)Rendahnya kemampuan mahasiswa dalam merancang sistem proteksi. Kelemahan tersebut disebabkan oleh beberapa faktor, antara lain minimnya media instruksional, penugasan yang tidak konstruktif, proses pembelajaran yang tidak memberi porsi cukup untuk pemecahan masalah dan perancangan sistem proteksi. Strategi pembelajaran cenderung menekankan penggunaan peralatan proteksi tetapi mengabaikan perancangan sistem. Selain itu rendahnya kemampuan awal mahasiswa juga menjadi penyebab rendahnya hasil belajar yang dicapai, selain factor lain yaitu motivasi belajarnya juga rendah.

Kelemahan di atas tidak boleh terus berlangsung sebab akan menimbulkan dampak negatif yaitu semakin rendahnya kompetensi lulusan. Apalagi kompetensi ini merupakan salah satu kompetensi utama dalam program studi untuk bidang energi listrik dan sangat dibutuhkan di dunia kerja. Kompetensi lulusan dalam bidang ini tidak hanya melaksanakan atau menggunakan perangkat proteksi pada sistem tenaga listrik, tetapi lebih dari itu yakni kompetensi merancang suatu sistem proteksi tenaga listrik sesuai kebutuhan.

Banyak penelitian yang mengungkap keberhasilan meningkatkan kompetensi mahasiswa, salah satunya ialah melalui pembelajaran menggunakan multimedia. Multimedia mampu menciptakan suasana 
dan iklim belajar yang berkualitas dan meningkatkan kompetensi hasil belajar dalam bidang energi kelistrikan (Nortcliffe, \& Middleton, 2008; Malik, Mishra, and Shanblatt, 2008; Liao and Ganago,2011; Watai., Brodersen, and Brophy, 2005; Hohne \& Henkel, 2004; Hunt, Howard, Kirk, Ash, \& Tyrrell, 2001; Jennings \& Schoch, 1997). Selain itu, Romanas (2007) mengembangkan multimedia tutorial model classic tutorialyang meningkatkan hasil belajar bidang kelistrikan. Sun Jing \& Sun Yafei (2008) mengembangkan multimedia bidang energi listrik model exploratory tutorial, dan terbukti mampu meningkatkan hasil belajar. Amjad \& Nebras (2012) juga mengembangkan multimedia untuk teknik tenaga listrik dan terbukti mampu meningkatkan kompetensi hasil belajar secara berarti.

Selain multimedia, penerapan strategi peta konsep juga terbukti mampu meningkatkan hasil belajar mahasiswa. Penelitian membuktikan bahwa rendahnya hasil belajar karena tidak difahaminya konsep kunci atau hubungan antar konsep apa yang dipelajarinya (Zheng, et al, 2009; McMahon, 2007; Lauglo, 2005). Penelitian lain juga telah membuktikan bahwa penerapan strategi peta konsep mampu meningkatkan hasil belajar (Noprianto, 2006; Kadir, 2004;
Rusmansyah, 2001; Isnawati, 2000). Menyikapi rendahnya hasil belajar mahasiswa khusunya dalam perancangan sistem proteksi tenaga listrik, perlu untuk melakukan inovasi pembelajaran sebagai upaya untuk meningkatkan kompetensi hasil belajar mahasiswa. Mengacu kepada permasalahan maka perlu dilakukan inovasi pembelajaran. Dari analisis karakteristik dan permasalahan maka pembelajaran menggunakan multimedia dan penerapan strategi peta konsep dinilai tepat untuk meningkatkan kompetensi mahasiswa dalam perancangan sistem proteksi tenaga listrik.

\section{Kajian Pustaka \\ Kompetensi Hasil Belajar}

Kompetensi hasil belajar dalam kajian ini dapat dikelompokkan dalam tiga aspek yaitu: (1) Memahami konsep dasar sistem proteksi dan prinsip kerja peralatan, (2) Kompetensi aplikasi sistem proteksi sistem tenaga listrik, (3) Kompetensi melakukan pekerjaan pengembangan dan perencanaan proteksi sistem tenaga listrik sesuai kebutuhan. Bahan kajian meliputi tiga topik yaitu (1) Pembangkit listrik termasuk di dalamnya generator, motor dan transformator, (2) Saluran tenaga listrik yang meliputi gardu induk, saluran transmisi dan distribusi, (3) Beban yang dipikul sistem tenaga listrik. 


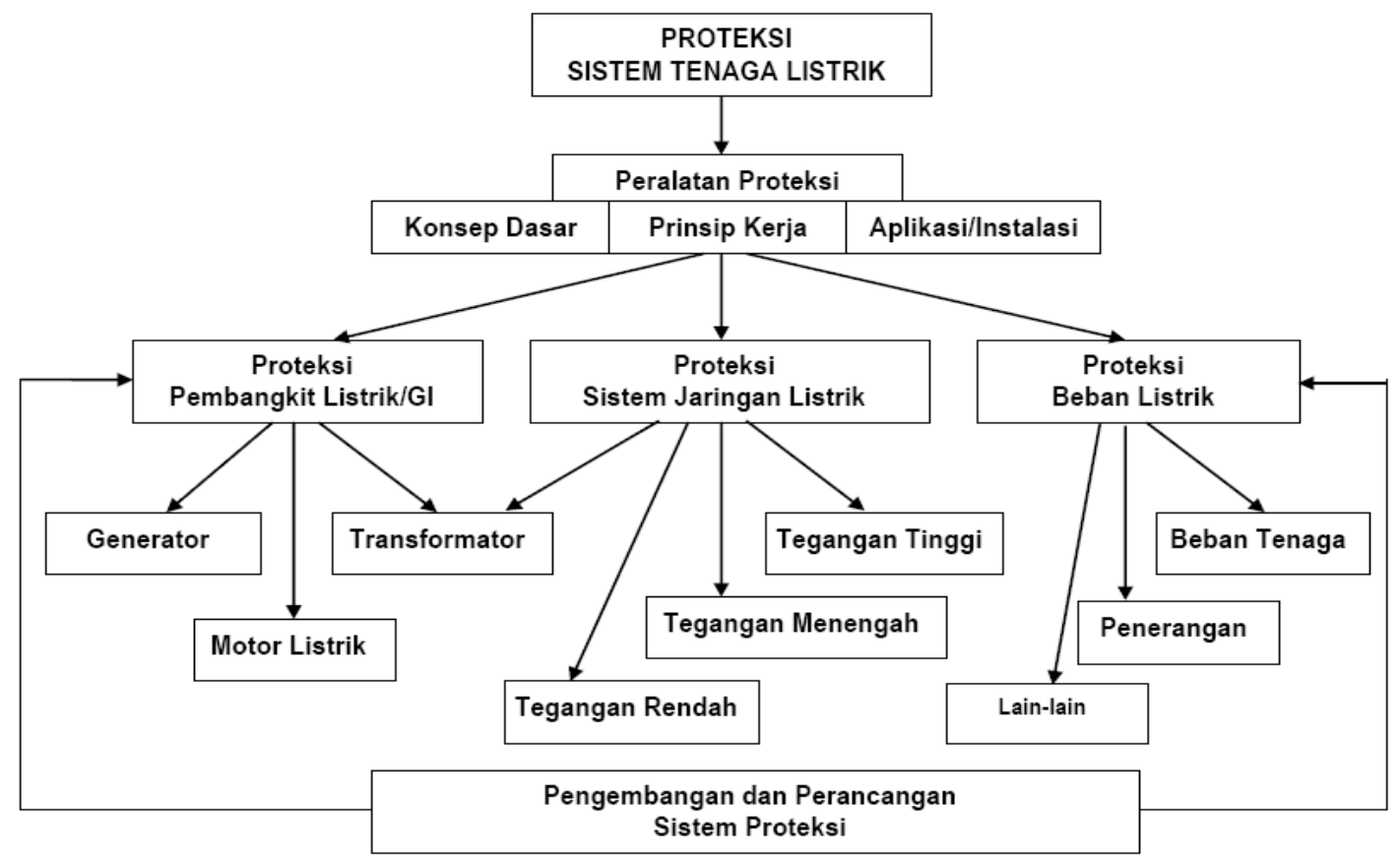

Gambar 1. Peta konsep proteksi sistem tenaga listrik

\section{Pembelajaran Berbasi Multimedia}

Pembelajaran berbasis multimedia mengacu kepada teori kognitivisme yang berkembang dalam dua pendekatan yaitu objektivisme dan konstruktivisme (Su 2009). Dari teori ini berkembang teori pemrosesan informasi (Driscoll, 2005; Ormrod, 2004). Proses kognitif terjadi dalam otak manusia mulai penerimaan, pemrosesan dan penyimpanan informasi serta pemanggilan informasi kembali dari otak (Schunk, 2004). Dalam teori memori kerja Baddeley (2009) ada empat komponen utama, yaitu visuospatial sketchpad, episodic buffer, phonological loop dan central executive

Proses pembelajaran akan lebih efektif jika menggunakan media instruksional yang dikembangkan dalam bentuk visual dan auditori (Wouters, Fred Paas \& Merriënboer, 2008). Ini merupakan azas pembelajaran multimedia, bahwa manusia dapat belajar akan lebih mudah apabila materi belajar disampaikan dalam bentuk visual dan auditori dibandingkan dengan bahasa lisan (Mayer, 2014). Konsep ini sesuai dengan teori dual-coding dari Paivio (2006) bahwa pelajar akan optimum menerima materi ajaran jika melibatkan asosiasi antara indra penglihatan (visual) dengan indra pendengaran (auditori). Hasil belajar akan lebih efektif jika proses pembelajaran menggunakan alat bantu multimedia.

Teori kognitif multimedia(Cognitive theory of multimedia learning) dari Clark \& Mayer (2008) merupakan perpaduan antara Cognitive load theory dari Sweller, Dual-coding theorydari Pavio dan Working memorymodeldari Baddeley (Mayer, 2014). Pemrosesan informasi terjadi dalam tiga tahapan penting, yaitu memilih bahan yang sesuai, menyusun bahan terpilih dan menggabungkannya dengan pengetahuan yang sudah dimiliki sebelumnya. Proses pemilihan bahan terjadi ketika individu memberi perhatian kepada bahan yang disampaikan melalui multimedia, dan membawanya masuk ke meori kerja dalam sistem kognitif. Proses penyusunan bahan terpilih dilakukan melalui seleksi bahan-bahan dalam memori kerja. Selanjutnya dilakukan 
integrasi bahan yang telah disusun dengan pengetahuan yang sudah dimiliki sebelumnya dari memori jangka panjang ke memori kerja. Aliran pemrosesan informasi dinyatakan dalam model teori kognitif pembelajaran multimedia seperti diperlihatkan pada gambar 2 .

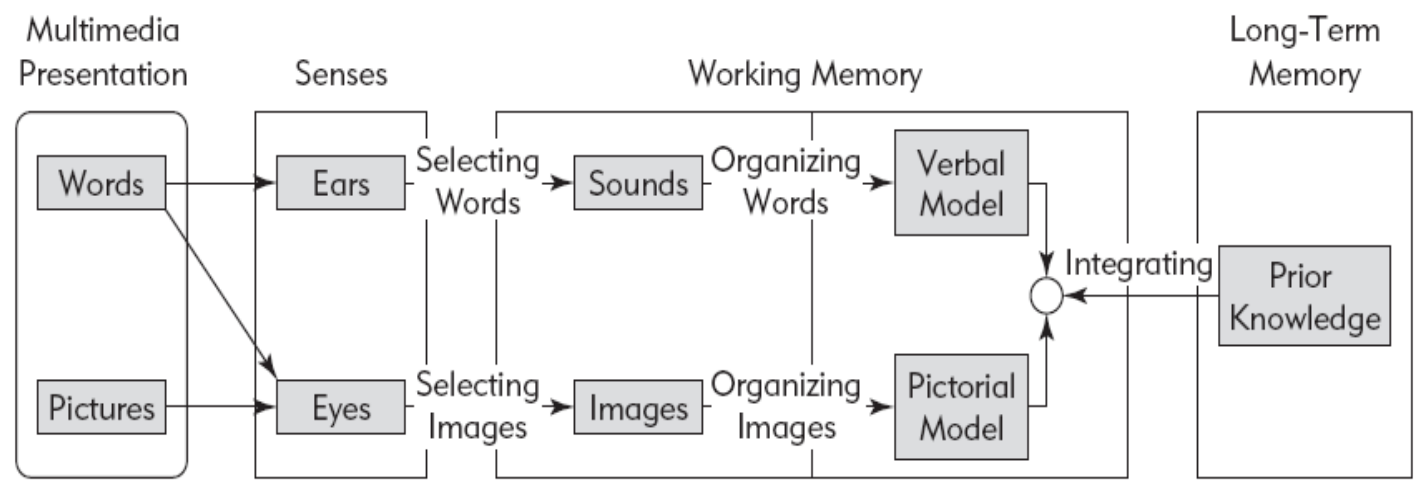

Gambar 2. Skema Teori Kognitif Pembelajaran Multimedia (Clark \& Mayer,2008)

Model pembelajaran ini menetapkan empat prinsip dari penelitian dalam sains kognitif (Clarck dan Mayer, 2008) yaitu :

Dual channel, manusia memproses informasi bentuk visual atau gambar dan auditori atau verbal dalam saluran yang terpisah.

Limited capacity, manusia dapat melakukan proses aktif hanya pada sebagian informasi di setiap saluran pada satu waktu tertentu.

Active processing, pembelajaran terjadi ketika individu terlibat dalam proses kognitif, seperti memperhatikan materi yang relevan, mengorganisasi materi ke dalam struktur koheren, dan mengintegrasikan dengan pengetahuan yang sudah mereka ketahui.

Transfer, pengetahuan baru dan keterampilan harus diambil dari memori jangka panjang selama proses.

Pembelajaran berbasis multimedia berlandaskan kepada prinsip tutorial. Multimedia pembelajaran yang efektif perlu memperhatikan setidaknya enam aspek utama, yaitu: (1) access; (2) cost; (3) technology; (4) interactivity; (5) organization dan (6) novelty (Kusnandar,
2003). Media instruksional yang baik harus memenuhi persyaratan. Wahono (2007) membagi media instruksional berbasis multimedia dalam tiga aspek yaitu (1) Aspek rekayasa perangkat lunak; (2) Aspek desain pembelajaran dan (3) Aspek komunikasi visual.

Multimedia sebagai alat bantu pengajaran sekaligus sebagai sumber belajar akan lebih efektif jika perisian materi ajar dibangun sesuai kaidah. Urutan pembelajaran dilakukan secara terstruktur sesuai dengan tujuan yang akan dicapai. Pemilihan urutan bahan bukan merupakan daftar lengkap, tetapi merupakan bahan yang paling diperlukan sesuai kurikulum.

Organisasi perisian materi belajar dalam bentuk media tutorial dikelompokkan dalam tujuh macam yaitu (1) Classic tutorial, (2) Activity centered tutorial, (3) Learner customized tutorial, (4) Knowledge-based tutorial, (5) Exploratory tutorial, (6) Drill \& practice tutorial dan juga (7) Generated lesson tutorial (Thomas, 2005; Horton, 2000). Selanjutnya pembelajaran dengan berbasis multimedia dapat dilakukan dengan alur seperti berikut. 


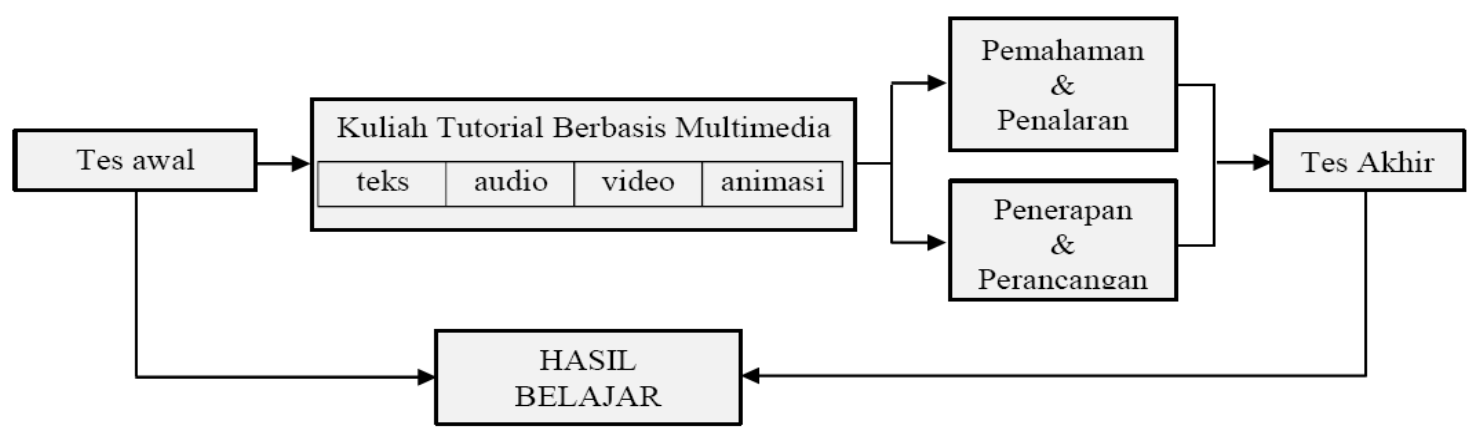

Gambar 3. Rancangan pembelajaran Berbasis Multimedia

Prosedur pembelajaran berbasis multimedia diawali dengan tes awal untuk mengetahui kemampuan sebelum mengikuti pembelajaran. Selanjutnya dilakukan orientasi pembelajaran beri pengarahan tentang proses pembelajaran menggunakan multimedia yang akan dilaksanakan. Proses pembelajaran dalam model multimedia ini dilakukan dengan belajar tatap muka dan dilanjutkan dengan pembelajaran tutorial yang menggunakan multimedia instruksional bagi setiap individu menggunakan multimedia yang dikembangkan. Multimedia berisikan bahan ajar dalam bentuk teks, visual, auditori, video dan animasi dengan sasaran kemampuan pemahaman, penalaran, penerapan dan perancangan. Setelah selesai satu unit pembelajaran dilakukan tes akhir.

\section{Strategi Peta Konsep}

Pembelajaran menggunakan peta konsep mementingkan aspek kognitif fundamental tentang konsep dan ciri-ciri objek dipelajari. Konsep merupakan kondisi utama yang diperlukan untuk dapat menguasai kemahiran tentang diskriminasi dan proses kognitif fundamental sebelumnya berdasarkan kesamaan ciri-ciri dari sekumpulan stimulus dan objeknya (Djamarah \& Zain, 2002). Novak (2005) menegaskan peta konsep sebagai alat atau strategi untuk membantu anak didik mengorganisasikan konsep perkuliahan yang dipelajari berdasarkan arti dan juga hubungannya. Hubungan satu konsep (informasi) dengan lainnya dikenal dengan proposisi, . yang merupakan dua atau lebih konsep yang dihubungkan oleh kata-kata dalam suatu unit semantik.

Pembelajaran dengan peta konsep dilakukan untuk memberikan makna dari apa yang dipelajari. Peta konsep memiliki 5 ciri yaitu (1) branches; (2) arrows; (3) gouping;(4) list, dan (5) explanatory notes). Konsep dinyatakan dalam bentuk istilah atau label konsep dijalin secara bermakna dengan kata-kata penghubung sehingga membentuk proposisi. Satu proposisi mengandung dua konsep dan kata penghubung. Konsep yang satu mempunyai cakupan yang lebih luas (inklusif) daripada konsep yang lain.

Selanjutnya konsep yang lebih inklusif diletakkan di atas dari konsep yang kurang inklusif dan kemudian dihubungkan. Konsep yang lebih khusus ditempatkan di bawahnya, dihubungkan lagi dengan kata penghubung. Konsep yang inklusif dapat dihubungkan dengan beberapa konsep kurang inklusif. Konsep yang paling inklusif diletakkan pada puncak pohon konsep, disebut dengan kunci konsep. Konsep pada jalur yang satu dapat dihubungkan dengan konsep pada jalur yang lain dengan kata penghubung, dan hubungan ini disebut dengan ikatan silang yang menunjukkan keterpaduan antarjalur pengembangan 
dalam bahasan yang disebut penyesuaian integratif.

Strategi peta konsep memperkirakan kedalaman dan keluasan yang perlu dipelajari. Kaitan konsep satu dengan konsep yang lain merupakan hal yang penting dalam belajar sehingga apa yang dipelajari akan lebih bermakna, lebih mudah diingat dan dipahami, dan diolah serta dikeluarkan kembali bila diperlukan (Trianto,2009; Nasution, 2008). Keadaan ini akan meningkatkan hasil belajar melalui proses yang lebih bermakna tentang materi yang dipelajarinya. Bagi para pendidik, strategi peta konsep bermanfaat: (1) Membantu mengerjakan apa yang telah diketahui, merencanakan dan memulai suatu topik pembelajaran, serta mengolah kata kunci yang akan digunakan. (2) Membantu mengingat kembali dan merevisi konsep belajar, membuat pola catatan kerja dan belajar yang baik. (3) Membantu mendiagnosis apa-apa yang diketahui dalam bentuk struktur. (4) Membantu mengetahui adanya miskonsepsi, contohnya dalam ujian akan tergambar kemampuan mengolah idenya dalam bentuk grafik ataupun penggunaan visual yang representatif. (5) Membantu memeriksa pemahaman akan konsep yang dipelajari, peta konsep yang dibuat sudah benar atau masih salah. (6) Membantu memperbaiki kesalahan konsep pada pembelajaran selanjutnya. (7) Membantu merencanakan pembelajaran dan evaluasi keberhasilan (Rusmansyah,2001).

Bagi mahasiswa strategi peta konsep bermanfaat untuk : (1) Membantu dalam mengidentifikasi kunci-kunci konsep, memperkirakan hubungan pemahaman dan membantu pembelajaran lebih lanjut. (2) Membantu membuat susunan konsep pelajaran menjadi lebih baik untuk keperluan ujian. (3) Membantu dalam menyediakan bahan pemikiran untuk menghubungkan konsep pembelajaran. (4) Membantu berpikir dengan ide dan menjadikan mereka mengerti benar akan pengetahuan. (5) Mengklarifikasi ide yang diperoleh tentang sesuatu dalam bentuk kata-kata. (6) Membuat struktur pemahaman bagaimana semua fakta-fakta baru dan eksis dihubungkan pengetahuan berikutnya. (7) Membantu aktivitas belajar mahasiswa bagaimana sebaiknya mengorganisasi sesuatu mulai dari informasi, fakta, dan konsep ke dalam suatu konteks pemahaman, sehingga terbentuk pemahaman yang benar.

Peta konsep ada empat macam, yaitu (1) Network tree; (2) Event chain; (3) Cycle Concept map; (4) Spider concept map (Nur, 2002). Penyusunan peta konsep dibutuhkan dalam proses belajar agar peserta didik mengetahui dan meyakini tentang makna dari apa yang sedang dipelajarinya, dan dapat menyusun dalam waktu yang relatif singkat diselingi dengan pekerjaan lain sambil memikirkan keterkaitan antar konsep sehingga membentuk suatu proposisi yang membuat belajar menjadi lebih bermakna.

Ada tujuh langkah yang harus diikuti untuk membuat peta konsep dengan benar, yaitu: (1) Memilih dan menentukan suatu bahan bacaan. (2) Bahan bacaan dapat dipilih dari buku atau bahan bacaan yang lain. (3) Menentukan konsep-konsep yang relevan, (4) Mengurutkan konsep-konsep dari paling umum sampai paling khusus atau contoh-contoh. (5)Menyusun konsepkonsep,memetakan berdasarkan kriteria dari konsep yang paling umum di puncak, konsep-konsep pada tingkatan abstraksi sejajar satu sama lain, dan konsep lebih khusus di bawah konsep yang lebih umum.(6) Menghubungkan konsepkonsep dengan kata penghubung tertentu untuk membentuk proposisi dan garis penghubung. (7) Setelah peta selesai, perlu diperhatikan kembali letak konsepkonsepnya dan jikadirasa perlu dapat diperbaiki atau disusun kembali agar menjadi lebih baik dan berarti. 
Pembelajaran dengan Peta Konsep

Implementasi model pembelajaran dalam studi ini dikembangkan dalam dua fase pembelajaran. Fase pertama adalah proses belajar mengajar reguler secara klasikal dengan menggunakan kombinasi metode pembelajaran yang sesuai dengan materi pembelajaran (kuliah tatap muka biasa/konevnsional). Fase kedua adalah pemberian tugas kepada mahasiswa dalam bentuk penyusunan peta konsep tentang materi perkuliahan yang telah dibahas dalam kuliah tatap muka. Penugasan ini dilakukan berkelompok dengan jumlah sekitar 5 orang setiap kelompoknya. Hasil pekerjaan kelompok untuk pengembangan peta konsep akan dipresentasikan pada perkuliahan tatap muka dan ditanggapi oleh kelompok lain. Hasil pembahasan tugas peta konsep ini dirangkum menjadi kesimpulan bersama.

Setelah beberapa satuan unit perkuliahan disajikan maka dilakukan tes formatif. Analisis capaian hasil belajar mahasiswa dijadikan sebagai masukan untuk perbaikan pada perkuliahan berikutnya. Pada pertemuan terakhir akan dilakukan tes final sekaligus mengetahui capaian hasil belajar mahasiswa yang dikembangkan dengan strategi peta konsep. Proses pembelajaran dengan model penerapan strategi peta konsep ini dinyatakan seperti gambar berikut.

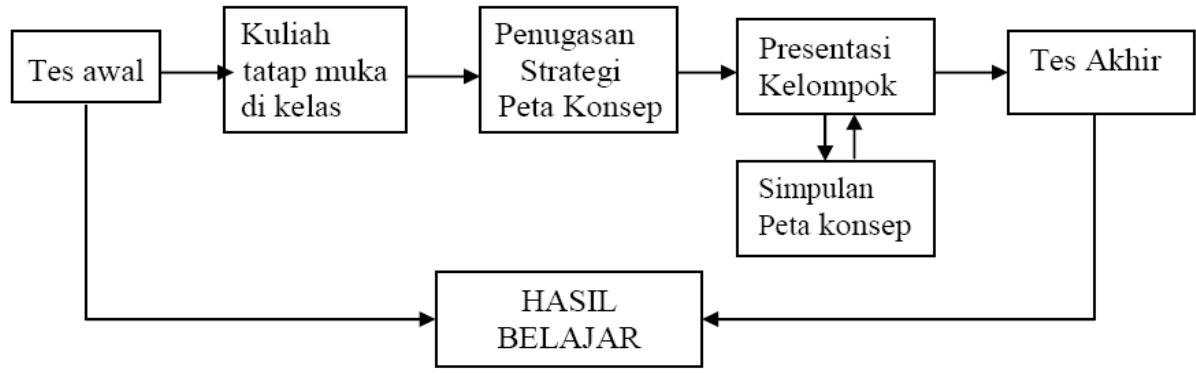

Gambar 3. Disain pembelajaran dengan strategi peta konsep

\section{Metode Penelitian}

Penelitian dilaksanakan dalam bentuk kuasi eksperimen, dengan mahasiswa peserta kuliah Proteksi Sistem Tenaga Listrik sebagai responden. Ada dua kelompok eksperimen dalam kajian ini yaitu pembelajaran berbasis multimedia $\left(\mathrm{X}_{1}\right)$ dan pembelajaran dengan strategi peta konsep $\left(\mathrm{X}_{2}\right)$. Instrumen tes dikembangkan dengan mengacu kepada kompetensi sesuai kurikulum, dan dilakukan uji validitas, reliabilitas, tingkat kesukaran dan daya pembeda. Hasil belajar (Y) sebagai variabel dependen diperoleh melalui tes hasil belajar, yaitu gain score dari final test dan pre test dan akan dikomparasikan antar ke dua kelompok tersebut. Analisis data menggunakan Z-test (two tail test), pada taraf $\alpha=5 \%$ setelah uji persyaratan khususnya normalitas dan homogenitas (Supranto, 2008; Harinaldi, 2005).

\section{Hasil Penelitian dan Pembahasan}

Kompetensi hasil belajar mahasiswa dalam perancangan sistem proteksi tenaga listrik tergolong baik pada kedua model pembelajaran. Pada pembelajaran berbasis multimedia diperoleh indeks keberhasilan $\mathrm{x}_{1}=3,48$ nilai minimum kurang kompeten (C) sebanyak $5,2 \%$ dan nilai maksimum kompeten (A) sebesar 34,2\%, sedangkan capaian belajar adalah $100 \%$ kelulusan, seperti disajikan pada Tabel 1. Sedangkan pada model pembelajaran dengan penerapan strategi peta konsep diperoleh indeks keberhasilan $\mathrm{x}_{2}$ adalah sebesar 3,11 dengan nilai terendah adalah gagal (E) sebesar 5,6\% dan nilai yang tertinggi adalah kompeten (A) sebesar $27,8 \%$, serta capaian belajar sebesar 94,4\% kelulusan. 
Selanjutnya sebaran data secara disajikan dalam Tabel 2.

Tabel 1. Deskripsi HB Pemb. Multimedia

\begin{tabular}{lcccc}
\hline & & Freq & Percent & $\begin{array}{c}\text { Cumulative } \\
\text { Percent }\end{array}$ \\
\hline Valid & $\mathrm{C}=2.0$ & 1 & 2.6 & 2.6 \\
& $\mathrm{C}+=2.5$ & 1 & 2.6 & 5.3 \\
& $\mathrm{~B}=3.0$ & 9 & 23.7 & 28.9 \\
& $\mathrm{~B}+=3.5$ & 14 & 36.8 & 65.8 \\
& $\mathrm{~A}=4.0$ & 13 & 34.2 & 100.0 \\
\cline { 2 - 5 } & Total & 38 & 100.0 & \\
Mean & & $: 3.48$ & & \\
Median & & $: 3.50$ & & \\
Mode & & $: 3.50$ & & \\
Std Dev & & 0.486 & & \\
Minimum & & $: 2.00$ & & \\
Maximum & & $: 4.00$ & & \\
\hline
\end{tabular}

Tabel 2. Deskripsi HB Pemb. Peta Konsep

\begin{tabular}{|c|c|c|c|c|}
\hline & & Freq & Percent & $\begin{array}{c}\text { Cumulative } \\
\text { Percent }\end{array}$ \\
\hline \multirow[t]{7}{*}{ Valid } & $E=0.00$ & 2 & 5.6 & 5.6 \\
\hline & $C=2.00$ & 3 & 8.3 & 13.9 \\
\hline & $C+=2.50$ & 3 & 8.3 & 22.2 \\
\hline & $B=3.00$ & 9 & 25.0 & 47.2 \\
\hline & $B+=3.50$ & 9 & 25.0 & 72.2 \\
\hline & $A=4.00$ & 10 & 27.8 & 100.0 \\
\hline & Total & 36 & 100.0 & \\
\hline Mean & & 3.11 & & \\
\hline Median & & 3.50 & & \\
\hline Mode & & 4.00 & & \\
\hline Std Dev & & 0.979 & & \\
\hline Minimum & & 0.00 & & \\
\hline Maximum & & 4.00 & & \\
\hline
\end{tabular}

Capaian untuk aspek kompetensi pada bidang proteksi sistem tenga listrik mengalami peningkatan yang sangat berarti seperti diperlihatkan pada tabel 3 .

Tabel 3. Capaian Aspek Kompetensi Hasil Belajar

\begin{tabular}{lcccccc}
\hline \multirow{2}{*}{ Kompetensi } & \multicolumn{6}{c}{ Aspek Kompetensi } \\
\cline { 2 - 7 } Konten & Konsep Dasar & \multicolumn{2}{c}{ Aplikasi } & \multicolumn{3}{c}{ Perancangan } \\
\cline { 2 - 7 } & MM & PK & MM & PK & MM & PK \\
\hline Pembangkit & 84 & 86 & 85 & 82 & 78 & 75 \\
Saluran TL & 78 & 82 & 86 & 84 & 75 & 74 \\
Pembebanan & 83 & 85 & 88 & 85 & 80 & 76 \\
\hline Mean & 81,67 & 84,33 & 86,33 & 83,67 & 77,67 & 75,00 \\
\hline
\end{tabular}

Pada aspek kompetensi konsep dasar model pembelajaran menggunakan strategi peta konsep lebih efektif dibandingkan dengan pembelajaran menggunakan multimedia, yaitu dengan rerata 84,33 berbanding 81,67 , tetapi pada aspek aplikasi dan perancangan justru pembelajaran berbasis multimedia jauh lebih efektif dengan capain hasil belajar lebih tinggi dibandingkan dengan pembelajaran dengan strategi peta konsep yaitu dengan rerata 86,33 dan 77,67 berbanding 83,67 dan 75,00 baik untuk materi pembangkit, saluran tenaga listrik dan juga pembebanan listrik.

Jika kompetensi hasil belajar dari dua model dikomparasikan, diperoleh hasil bahwa terdapat perbedaan yang signifikan capaian hasil belajar dari kedua model ini, pada taraf kepercayaan 95\%. Perbedaan ini memperlihatkan bahwa model pembelajaran berbasis multimedia lebih efektif dalam upaya meningkatkan kapabilitas capaian hasil belajar mahasiswa dalam mata kuliah Proteksi Sistem Tenaga Listrik. Ringkasan hasil pengujian diperlihatkan pada Tabel 4 dan Tabel 5 berikut.

Tabel 4. Statistik Nilai HB Dua Model Pembelajaran

\begin{tabular}{clcccc}
\hline & Model_Pembelajaran & $\mathrm{N}$ & Mean & SD & SE Mean \\
\hline \multirow{4}{*}{ Hsl Belajar } & Pemb.Multimedia & 38 & 3.48 & .486 & .078 \\
\cline { 2 - 6 } & Pemb.Peta Konsep & 36 & 3.11 & .979 & .163 \\
\hline
\end{tabular}

Tabel 5. Ringkasan Uji Komparatif 2 Mean

\begin{tabular}{ccccccc}
\hline & \multicolumn{3}{c}{ Lev.Test for EV } & $\begin{array}{c}\text { t-test for Equality of } \\
\text { Means }\end{array}$ \\
\cline { 2 - 7 } & F & Sig. & $\mathrm{t}$ & $\mathrm{df}$ & Sig. \\
\hline \multirow{3}{*}{ Hsl Belajar } & $\begin{array}{l}\text { Equal variances } \\
\text { assumed }\end{array}$ & 7.03 & .010 & 2.11 & 72 & .039 \\
\cline { 2 - 7 } & $\begin{array}{l}\text { Equal variances } \\
\text { not assumed }\end{array}$ & & 2.07 & 50.64 & .043 \\
\hline
\end{tabular}

Model pembelajaran berbasis multimedia sebagai variabel independen pertama dilaksanakan kuasi eksperimen dengan sampel sebanyak 38 orang. Hasil penelitian menemukan bahwa rerata hasil belajar 3,48 sedangkan pada model pembelajaran dengan penerapan strategi peta konsep dengan 36 responden mendapatkan rerata hasil belajar 3,11. Hasil uji komparasi pada taraf $\alpha=5 \%$ diperoleh harga th $=2,11$ di mana harga tersebut signifikan karena signifikansi hasil pengujian dibawah 0,05 . Dengan demikian penelitian telah membuktikan bahwa pembelajaran berbasis multimedia mampu meningkatkan hasil belajar mahasiswa dalam perancangan proteksi 
sistem tenaga listrik. Model pembelajaran multimedia ini lebih efektif dalam upaya meningkatkan kapabilitas hasil belajar dibandingkan dengan model pembelajaran menggunakan peta konsep, dan pada taraf kepercayaan $95 \%$ diterima kebenarannya sangat signifikan.

Selanjutnya dibandingkan dengan indikator kinerja yang selama ini hasil capaian penelitian dapat dilihat pada Tabel 6 berikut.

Tabel 6. Capaian Indikator Kinerja

\begin{tabular}{cccccl}
\hline \multirow{2}{*}{ No } & Indikator & Base- & \multicolumn{2}{c}{ Capaian } & \multirow{2}{*}{ Kinerja } \\
\cline { 4 - 5 } & line & MM & PK & \\
\hline 1 & Kompeten (A) & $13.2 \%$ & $34,2 \%$ & $27,8 \%$ & Meningkat \\
2 & Gagal (E) & $8.81 \%$ & $0 \%$ & $5,6 \%$ & Menurun \\
3 & Indeks Nilai & 2,92 & 3,48 & 3,11 & Meningkat \\
\hline
\end{tabular}

Tabel 6 memperlihatkan bahwa kedua model pembelajaran terbukti mampu meningkatkan capaian hasil belajar dalam mata kuliah Proteksi Sistem Tenaga Listrik. Pada pembelajaran berbasis multimedia mampu mencapai hasil belajar peringkat kompeten (A) sebesar 34,2\% dari baseline $13,2 \%$, dan mahasiswa yang gagal juga $0 \%$ sementara indekas nilai meningkat menjadi 3,48 dari baseline yang hanya 2,92. Demikian juga dengan pembelajaran dengan strategi peta konsep yang juga mampu meningkatkan capaian hasil belajar dengan $27,8 \%$ berhasil meraih tingkat kompeten (A) dari baseline $13,2 \%$, dan menurunkan mahasiswa gagal menjadi $5,6 \%$ dari baseline $8,81 \%$ serta meningkatkan indeks nilai menjadi 3,11 dari baseline 2,92. Meskipun jika dibandingkan dengan pembelajaran berbasis multimedia masih lebih rendah akan tetapi secara keseluruhan model pembelajaran peta konsep ini mampu meningkatkan kapabilitas hasil belajar mahasiswa dibandingkan dengan baseline selama ini.

Kegagalan mahasiswa sebanyak 5,6\% pada pembelajaran strategi peta konsep lebih disebabkan oleh karena lemahnya kemampuan mahasiswa, terutama dalam memahami peristiwa abstrak dan konseptual sehingga mereka sulit untuk mengaplikasikan konsep-konsep tersebut dalam pemecahan masalah, apalagi untuk menyusun suatu perancangan sistem proteksi tenaga listrik.

\section{Penutup}

Pembelajaran dengan berbasis multimedia dan pembelajaran dengan strategi peta konsep sama-sama memiliki keunggulan dalam upaya meningaktkan hasil belajar dalam mata kuliah Proteksi Sistem Tenaga Listrik, lebih-lebih pada aspek kompetensi perancangan sistem proteksi. Jika dibandingkan dengan baseline yang selama ini menggunakan pembelajaran konvensional, model pembelajaran berbasis multimedia terbukti mampu meningkatkan hasil belajar dengan pertambahan capaian perolehan nilai A sebanyak $21 \%$ dari baseline, dan penuntasan belajar kelulusan $100 \%$ serta peningkatan indeks nilai matakuliah sebesar 0,56.

Pada pembelajaran dengan strategi peta konsep juga mampu meningkatkan capaian belajar tingkat kompeten 14,6\% dari baseline, dan penurunan angka kegagalan 3,21\% serta peningkatan indeks nilai sebesar 0,11 dari baseline. Namun demikian model ini masih lebih rendah efektivitasnya dibandingkan dengan model pembelajaran berbasis multimedia, baik dalam capaian tingkat kompetensi, penurunan persentase kegagalan dan juga peningkatan indeks nilai matakuliah.

Mengingat beberapa keterbatasan dalam kajian ini, untuk penelitian selanjutnya perlu juga diteliti masalah gaya belajar mahasiswa sebagai variabel moderator, sebab dalam kenyataannya gaya belajar ini juga mempengaruhi efektivitas belajar mahasiswa baik pada pembelajaran berbasis multimedia maupun pada pembelajaran dengan penerapan strategi peta konsep. Dengan demikian dapat diungkap pengaruh gaya belajar dan interaksinya dengan model pembelajaran yang mengacu kepada capaian kapabilitas hasil belajar. 


\section{Daftar Pustaka}

Amjad F. Hajjar \& Nebras M. Sobahi. (2012).Basic electrical engineering for non-majors: course design and implementation. Global Journal of Engineering Education. 4 (1), 47-56.

Djamarah, Syaiful Bahri \& Zain, Aswan (2002). Strategi Belajar-mengajar. Jakarta : Rineka Cipta.

Baddeley,A., Eysenck,M.W., \& Anderson,M.C.(2009). Memory. New York : Psychology Press.

Clark, Ruth Colvin., \& Mayer, R.E. (2008). e-Learning and the Science of Instruction, 2nd Ed. San Francisco : John Wiley \& Sons, Inc.

Driscoll, M.P (2005). Psychology of Learning for Instruction. Boston :, MA: Allyn \& Bacon Publishers.

Gilbert,J.K(2004).Model and modeling : Route to more authentic science education. International Journal of Science and Mathemetics Education, 12, 115-130.

Halloun, Ibrahim,A (2006). Modeling Theory in Science Education. Netherland : Springer.

Harinaldi (2005). Statistika untuk Teknik dan Sains. Jakarta : Erlangga

Höhne, G., \& Henkel, V. (2004). Application of multimedia in engineering design education. European Journal of Engineering Education, 29(1), 87-96.

Horton, William. (2000). Designing Web Based Training, John Wiley \& Son Inc. USA.

Hunt, A., Howard, D. M., Kirk, R., Ash, K., \& Tyrrell, A. M. (2001). Interactive multimedia systems for engineering education in acoustics, synthesis and signal processing. European Journal of Engineering Education, 26(2), 91-106.

Isnawati. (2000). Penerapan Strategi Peta Konsep (Concept Mapping) sebagai Upaya Meningkatkan Kemampuan Siswa. Banjarmasin : Proyek JSE Depdiknas Kalsel.
Kadir. (2004).Efektivitas strategi peta konsep dalam pembelajaran sain dan matematika(Meta analisis penelitian experimen psikologi dan pendidikan). Jurnal Pendidikan dan Kebudayaan, $\mathrm{X}$ (51), 761-781.

Kirkwood, V. and Symington,D. (1996). Lecture perceptions of student difficulties in first year chemistry course. Journal of Chemical Education, 73.

Kusnandar, Ade (2003). Guru dan Media Pembelajaran.Jurnal Teknodik.7 (13).

Lauglo, J. (2005). Vocationalised secondary education revisited. Dalam J. Lauglo \& R. Maclean (Eds.), Vocationalisation of Secondary Education Revisited. Springer: Dordrecht. 3-49

Liao, H. and Ganago, A.(2011). Student Learning in Electrical Engineering (EE) Lab Project for Non-EE Majors: From Technical Skills to Multidisciplinary Teamwork. Paper Presented at the Dep. Of ECE, University of Michigan, Ann Arbor.

Malik, Q.H., Mishra, P. and Shanblatt, M.(2008). Identifying learning barriers for non-major engineering students in electrical engineering courses. Proc. 2008 ASEE North Central Section Conf., Dayton, Ohio.

Mayer, R.E.(2014). Multimedia Learning. $\left(2^{\text {nd }}\right) \quad$ New York:Cambridge University Press.

McMahon,G.P. (2007). Getting hots with what's in the box: Developing high order thinking skills within a technology-rich learning environment. Disertasi Doktor Falsafah, Tidak diterbitkan. Curtin University of Technology.

Muhammad Nur (2002). Psikologi Pendidikan : Pondasi untuk Pengajaran. Surabaya : PSMS Program Pascasarjana Unesa.

Nasution S (2008). Berbagai Pendekatan dalam Proses Belajar dan Mengajar (Ed.12). Jakarta : Bumi Aksara. 
Nortcliffe, A., \& Middleton, A. (2008). A three year case study of using audio to blend the engineer's learning environment. Engineering Education, $3(2), 45-52$.

Novrianto, Adien (2006). Keefektifan Strategi Pengajaran Menggunakan Peta Konsep Ditinjau dari Prestasi dan Retensi Belajar Siswa. Tesis tidak diterbitkan. Malang: PPS Universitas Negeri Malang.

Ormrod, J.E. (2004). Educational Psychology. Upper Saddle River. New Jersey : Prentice Hall.

Paivio,Allan. (2006). Dual coding theory and education. Pathways to Literacy Achievement for High Poverty Children. The University of Michigan School of Education.

Robert Zheng, et al, (2009). Effects of multimedia on cognitive load, selfefficacy, and multiple rule-based problem-solving. Journal of Educational Technology, 40(5), 790-803

Romanas, V. Krivickas \& Jonas, Krivickas (2007). Laboratory Instruction in Engineering Education. Global Journal. of Engineering Education. 11(2): 191-196

Rusmansyah (2001). Meningkatkan Pemahaman Siswa Terhadap Konsep Kimia Karbon Melalui StrategiPeta Konsep. Banjarmasisn: Penelitian PPD HEDS,

Sriadhi. (2013). Analisis Kesulitan Mahasiswa dalam Perancangan Proteksi Sistem Tenaga Listrik. FT Unimed, Laporan Penelitian.

Schunk, D.H. (2004). Learning Theories : An Educational Perspective, $\left(4^{\text {th }}\right)$. Upper Saddle, New Jersey : Merill Prentice-Hall.
Su, K.D. (2008). An integrated science course designed with information communication technologies to enhance university students' learning performance.Computers \& Education.http://www.elsevier.com/lo cate/compedu.

Sun Jing \& Sun Yafei. (2008). Optimization electrical engineering teaching utilize multimedia courseware.Computer Science and Software Engineering, 2008 International Conference. IEEE (5), Supranto, J (2009). Statistik : Teori dan Aplikasi. (ed 7). Jakarta : Erlangga

Thomas, Kent. (2004). Learning Sequences. New York : Rocky Mountain Alchemy.

Trianto (2009). Mendesain Model Pembelajaran Inovatif Progresif : Konsep, Landasan dan Imple-mentasi pada Kurikulum Tingkat satuan Pendidikan (KTSP). Jakarta : Kencana Prenada Media Group.

Wahono, Romi Satria (2007). Aspek dan KriteriaPenilaian Media Pembelajaran. http://www.RomiSatriaWahono.net.

Watai, L., Brodersen, A. and Brophy, S.(2005), Designing effective electrical engineering laboratories using challenge-based instruction that reflect engineering process. Proc. 2005 American Society of Engng. Educ. Annual Conf. and Exposition,ASEE'05, Oregon.

Wouters, P,Fred Paas.,\& Jeroen J. G. van Merriënboer. (2008). How to optimize learning from animated models: A review of guidelinesbased on cognitive load. Review od Educational Research, 78, 645. 